\title{
Variations on Some Common Topics in Medieval Latin Letters: The Case of the Salzburg Formulae Collection (Late Ninth Century)
}

\begin{abstract}
The Latin manuscript 4650 of the Bavarian State Library is a collection of templates for charters and letters (so-called formulae) most probably written in Salzburg in the late ninth or early tenth century. Some of these formulae have only been transmitted in that manuscript, but most have been transmitted elsewhere as collections and were probably composed a few generations earlier. It is therefore obvious that this manuscript is a patchwork (or the copy of such a heterogeneous collection), but the heterogeneity of the sources is not apparent at first sight. Only a close analysis of the sequence of the formulae, the use of red ink, and small textual changes permits an appreciation of the technique of medieval scribes when adapting previous models for the creation of new collections more suitable to their own needs.
\end{abstract}

This article deals with the ways in which medieval scribes used letters or models for letters to create new templates for their own use. During the early Middle Ages (c. 500-1050), models of this kind were often copied as collections containing templates for charters as well as models for writing letters, both of which were called formulae. ${ }^{1}$ This study is devoted to a collection made in Carolingian times and preserved in the manuscript Munich, Bayerische Staatsbibliothek, Clm 4650 (or Clm 4650 for short). This rather small codex $(135 \times 107 \mathrm{~mm})$ was written around the end of the ninth or the beginning of the tenth century. ${ }^{2}$ The quality of

1 On collections of formulae, see Brown 2009; Rio 2009. On medieval letters, see Constable 1976; Perelman 1991; Ysebaert 2015. On formularies as a mixture of letters and charters, see Depreux (forthcoming).

2 A description can be found in Glauche 1994, 283-284; Rio 2009, 247-248. For more information on the codex, see the book on East Frankish manuscripts containing collections of formulae to be published by Till Hennings and myself.

Ә Open Access. (C) 2021 Philippe Depreux, published by De Gruyter. (cc) BY-NC-ND This work is licensed under the Creative Commons Attribution-NonCommercial-NoDerivatives 4.0 International License.

https://doi.org/10.1515/9783110741124-020 
the parchment is average: ${ }^{3}$ the volume is not a deluxe edition, but a booklet intended for everyday use.

Most of the codices containing formulae are miscellaneous manuscripts. Only a few of them just contain templates for charters and letters. Clm 4650 is one of these; a medieval scribe who lived later, probably in the eleventh century, wrote at the top of the first folio that the codex was a 'handbook for various matters' (fol. $1^{\mathrm{r}}$ : liber breviarius uniuscuiusque rei), and a late medieval scribe wrote on the verso of the cover sheet that it was a 'formulary for letters' (formularius epistolarum) - in noting this, he was only focusing on one specific kind of text copied in the codex, though. Because of a mistake made by a bookbinder, the manuscript is not preserved in its original form, but the right order can easily be restored. The end of the codex has been lost, however. ${ }^{4}$

During the Middle Ages, this manuscript was kept at Benediktbeuern Abbey from at least the eleventh century onwards, but it was probably written in or near Salzburg. ${ }^{5}$ The close connection to the archbishopric church of Salzburg is attested in some of the charter models by the mention of saints who were particularly revered in Salzburg. ${ }^{6}$ Since formulae are generally anonymised documents, such information is excellent evidence of the collection's place of composition. For this reason, the editors of the collection in the nineteenth century called it the 'Salzburg Formulary' (Salzburgisches Formelbuch ${ }^{7}$ - meaning the whole codex or Formulae Salzburgenses ${ }^{8}$ [abbreviated as Form. Salzb. hereinafter] when referring to the formulae transmitted at the end of the manuscript).

3 By way of example, the size of fol. 38 and fol. 65 is smaller than the others because the scribe used waste leaf.

4 Rozière 1859, 11; Bischoff 1980, 201-202. See the table in the present article indicating the right order of the quires and the precise description of their content.

5 Bischoff 1980, 201-202; Bierbrauer 1990, 78-79 (Kat. 144).

6 Rozière 1859, 13; Schröder 1892, 165-166.

7 Rockinger 1858, 45 (concerning the whole manuscript).

8 Zeumer 1886, 438 (specifically relating to the models only preserved in that manuscript). 


\section{The homogeneity of a heterogeneous manuscript}

Clm 4650 contains formulae of diverse origin copied without any indication of their heterogeneous provenance; the layout is very uniform, in fact. ${ }^{9}$ It is unclear whether the scribe made a selection himself or if he copied a ready-made collection that was at his disposal. Consequently, it is hard to say if he was aware he was copying texts that belonged to various collections. Indeed, it is unclear whether these different collections ever existed in the form in which they were published in the late nineteenth century. Traditionally, Clm 4650 has been described - and perceived - as a series of three collections, ${ }^{10}$ but this is actually far from certain. Historians were sure for a long time that these formulae belonged to different collections, but we now know that these 'certitudes' need to be treated with great caution, as Karl Zeumer's edition is an 'editorial fiction' in many cases. ${ }^{11}$ Along with the Formulae Salzburgenses and a small collection of letters written by Alcuin framing the end of the codex, we find texts edited by Zeumer as parts of collections arbitrarily called Formulae Salicae Lindenbrogianae, Additamenta to the Formulae Salicae Lindenbrogianae and Formulae Marculfinae aevi Karolini. ${ }^{12}$ None of these collections have been copied en bloc: $\mathrm{Clm} 4650$ is a patchwork - albeit a nicely arranged one (or a copy of one) since no transition from one quire to another coincides with a rupture within a text (or - in the case of the first and second quire - within a coherent group of texts). The following overview should make this clear.

9 Sonnlechner 2007, 215: 'Ebenso sticht die Regelmäßigkeit des Buchblocks ins Auge, wie die gesamte Handschrift auch generell einen homogenen Eindruck macht und eine einheitliche Konzeption erkennen läßt'.

10 Schröder 1892, 165: 'Nach ihrem Inhalte zerfällt diese Sammlung in drei Teile, von denen die beiden ersten auch als selbständige Sammlungen vorkommen [...]. Der Salzburger Kompilator hat [...] diese im Lande [i.e. Bavaria] schon bekannte Sammlung nur durch Hinzufügung des die eigentlichen Salzburger Formeln enthaltenden dritten Teils erweitert'; Sonnlechner 2007, 214: 'Dieser Codex enthält drei Sammlungen, zuallererst die sogenannten Formulae Salicae Lindenbrogianae, dann die sogenannten Formulae Marculfinae aevi Karolini und schließlich die Formulae Salzburgenses'.

11 Brown 2013, 129 (referring to Rio 2009).

12 See Rio 2009, 101-110 on these collections. 
Table 1: Formulae collections in Clm 4650

\begin{tabular}{|c|c|c|c|}
\hline Quire & Folios & Text & Edition \\
\hline 1 & $1^{r}-7^{v}$ & Form. Sal. Lindenbrog., nos 1-7 & Zeumer $1886,266-271$ \\
\hline \multirow[t]{2}{*}{2} & $8^{r}-15^{v}$ & Form. Sal. Lindenbrog., nos 8-14 & Zeumer $1886,271-277$ \\
\hline & $15^{v}$ & $\begin{array}{l}\text { Form. Sal. Lindenbrog., Additamenta, no. } 1 \\
\text { (beginning) }\end{array}$ & Zeumer 1886, 282 \\
\hline \multirow[t]{2}{*}{3} & $16^{r}-18^{r}$ & $\begin{array}{l}\text { Form. Sal. Lindenbrog., Additamenta, nos } 1 \\
\quad \text { (end)-3 }\end{array}$ & Zeumer $1886,282-283$ \\
\hline & $18^{r}-23^{v}$ & Form. Sal. Lindenbrog., nos 15-20 (beginning) & Zeumer $1886,277-281$ \\
\hline \multirow[t]{2}{*}{5} & $32^{r}-33^{r}$ & Form. Sal. Lindenbrog., nos 20 (end)-21 & Zeumer 1886, 281-282 \\
\hline & $33^{r}-39^{v}$ & $\begin{array}{l}\text { Form. Marculfinae aevi Karol., nos 1-12 } \\
\text { (beginning) }\end{array}$ & Zeumer $1886,115-119$ \\
\hline \multirow[t]{4}{*}{4} & $24^{\mathrm{r}}-25^{\mathrm{v}}$ & Form. Marculfinae aevi Karol., nos 12 (end)-14 & Zeumer $1886,119-120$ \\
\hline & $25^{v}-28^{v}$ & Form. Marculfinae aevi Karol., nos 17-21 & Zeumer $1886,120-122$ \\
\hline & $28^{v}-29^{r}$ & Form. Sal. Lindenbrog., Additamenta, no. 4 & Zeumer 1886, 283-284 \\
\hline & $29^{r}-31^{v}$ & $\begin{array}{l}\text { Form. Marculfinae aevi Karol., nos 22-25 } \\
\text { (beginning) }\end{array}$ & Zeumer $1886,122-124$ \\
\hline \multirow[t]{2}{*}{8} & $56^{r}-63^{r}$ & $\begin{array}{l}\text { Form. Marculfinae aevi Karol., nos } 25 \text { (end)- } \\
\quad 31 \text { [finit] }\end{array}$ & Zeumer $1886,124-127$ \\
\hline & $63^{r-v}$ & Form. Salzb., nos 1-2 (beginning) & Zeumer $1886,439-440$ \\
\hline \multirow[t]{3}{*}{9} & $64^{r}-66^{v}$ & Form. Salzb., nos 2 (end)-6 & Zeumer $1886,440-441$ \\
\hline & $66^{v}-68^{r}$ & Moral and spiritual considerations ${ }^{13}$ & Rockinger $1858,133-134$ \\
\hline & $68^{r}-71^{v}$ & Form. Salzb., nos 7-16 (beginning) & Zeumer $1886,441-444$ \\
\hline \multirow[t]{3}{*}{6} & $40^{r}-41^{v}$ & Form. Salzb., nos 16 (end)-20 (beginning) & Zeumer $1886,444-445$ \\
\hline & $41^{v}-42^{v}$ & Moral and spiritual considerations ${ }^{14}$ & Rockinger $1858,141-142$ \\
\hline & $42^{v}-47^{v}$ & Form. Salzb., nos 20 (end)-39 (beginning) & Zeumer $1886,445-448$ \\
\hline
\end{tabular}

13 Jam quondam fidelis mentem .... in anima coram Deo proficiendo solet esse. There is no physical border between Form. Salzb. 6 and these moral and spiritual considerations (only the first letter of the latter is marked in red). This text was also edited by Rozière (1859, 38-39). Karl Zeumer did not edit it, as he thought that these spiritual considerations had nothing to do with formulae (Zeumer 1886, 441, footnote 6d: 'quae in c. sequuntur omisi, cum ad formulam pertinere non viderentur').

14 Erat quidam iudex in civitate .... ut non desinat esse quod antea fuit. There is no physical separation between Form. Salzb. 20 and these moral and spiritual considerations either (only the first letter of the latter is marked in red). This text was also edited by Rozière (1859, 44-45). Karl Zeumer chose not to edit it for a similar reason to the one just mentioned (Zeumer 1886, 445, n. 20c). 


\begin{tabular}{|c|c|c|c|}
\hline Quire & Folios & Text & Edition \\
\hline \multirow[t]{3}{*}{7} & $48^{r-v}$ & Form. Salzb., nos 39 (end) -43 & Zeumer $1886,448-449$ \\
\hline & $48^{v}-49^{r}$ & Questions and answers on God and creation ${ }^{15}$ & Rockinger $1858,151-152$ \\
\hline & $49^{r}-55^{v}$ & Form. Salzb., nos 44-60 (beginning) & Zeumer $1886,449-453$ \\
\hline \multirow[t]{2}{*}{11} & $80^{r}-84^{v}$ & Form. Salzb., nos 60 (end)-66 & Zeumer $1886,453-455$ \\
\hline & $84^{v}-85^{v}$ & $\begin{array}{l}\text { Alcuin, letter no. } 294 \text { (to an English pupil) } \\
\text { (beginning) }\end{array}$ & Dümmler 1895, 451-452 \\
\hline \multirow[t]{9}{*}{10} & $72^{r-v}$ & Alcuin, letter no. 294 (end) & Dümmler 1895, 452 \\
\hline & $72^{v}-74^{r}$ & Alcuin, letter no. 107 (to Arn of Salzburg) & Dümmler 1895, 153-154 \\
\hline & $74^{r}-75^{r}$ & Alcuin, letter no. 167 (to Arn of Salzburg) & Dümmler 1895, 275 \\
\hline & $75^{r}-76^{r}$ & Alcuin, letter no. 146 (to Arn of Salzburg) & Dümmler 1895, 235-236 \\
\hline & $76^{\mathrm{r}}-77^{\mathrm{v}}$ & Alcuin, letter no. 165 (to Arn of Salzburg) & Dümmler 1895, 267-268 \\
\hline & $77^{v}-78^{v}$ & Alcuin, letter no. 150 (to Arn of Salzburg) & Dümmler 1895, 245-246 \\
\hline & $78^{v}-79^{r}$ & $\begin{array}{l}\text { Alcuin, letter no. } 153 \text { (possibly to Arn of } \\
\text { Salzburg) }\end{array}$ & Dümmler 1895, 248 \\
\hline & $79^{r-v}$ & $\begin{array}{l}\text { Alcuin, letter no. } 173 \text { (to Arn of Salzburg) } \\
\text { (beginning }{ }^{16} \text { ) }\end{array}$ & Dümmler 1895, 286 \\
\hline & $79^{v}$ & $\begin{array}{l}\text { Alcuin, letter no. } 156 \text { (to Arn of Salzburg) } \\
\quad \text { (beginning }^{17} \text { ) }\end{array}$ & Dümmler 1895, 253 \\
\hline
\end{tabular}

Clm 4560 opens with the Formulae Salicae Lindenbrogianae. These formulae are also transmitted in a manuscript written in the late ninth century and now kept at The Royal Library in Copenhagen. ${ }^{18}$ In the middle of this collection there are three templates that have only been transmitted here ${ }^{19}$ (Zeumer called them 'supplements': additamenta). The first one is a model for a mutual donation between married people (carta inter virum et uxorem), which is an abbreviated adaptation

15 Interrogatio: Quid sit inter substantiam .... et una divinitas. There is no physical separation between Form. Salzb. 43 and this questioning either (the abbreviation for interrogatio and the first letter of the phrase are marked in red, though). The questioning is a heavily abbreviated summary of a letter that Alcuin sent his pupil Arn, who later became the archbishop of Salzburg: Dümmler 1895, 426-427 (no. 268).

16 The text ends abruptly in the middle of a phrase (Dümmler 1895, 2861. 18: per rivolos sanctitatis). 17 The next quire has been lost; the text ends with licet dubitationem aliquam (Dümmler 1895, 2531.14).

18 Copenhagen, Det Kongelige Bibliotek, Gl. Kgl. Saml. $19434^{\circ}$; description in Rio 2009, 242-243. 19 Rio 2009, 108. 
of a widely circulated late Merovingian formula on the same topic (Marculf, II, no. 7; the Marculfian formula contains a more detailed description of the goods that a man gives his wife and the gift she makes him in return). ${ }^{20}$ Both of the other formulae are model texts for making a donation to a church (donacio ad ecclesiam Dei and Donatio ad casam Dei). The beginning of the first one could be (but was not necessarily) influenced by a charter from Freising Cathedral. ${ }^{21}$ The following formulae are adaptations of other Marculfian formulae as well, some of which have also been transmitted in another manuscript written in the late ninth or early tenth century and now kept at Leiden University Library. ${ }^{22}$ Three of these formulae (Formulae Marculfinae aevi Karolini nos 15, 16, and 32) are only found in the Leiden manuscript. ${ }^{23}$ In the middle of these formulae in Clm 4650, there is a model of a circular announcing the death of a cleric or monk and asking for people to pray for his soul (Formulae Salicae Lindenbrogianae, Additamenta, no. 4). This model of a letter has also been transmitted in the Copenhagen manuscript mentioned previously. ${ }^{24}$ This is crucial evidence of how scribes could create a collection of formulae: they did not copy one collection slavishly, but invented compilations of their own on the basis of heterogeneous material they selected and adapted to their own needs. Some fragments of a ninth-century manuscript ${ }^{25}$ used for bookbinding prove that another collection with similar (but not exactly the same $)^{26}$ material existed elsewhere in Bavaria, namely in Saint-Emmeram (Regensburg). ${ }^{27}$

The next group of texts copied in Clm 4650 (i.e. the Formulae Salzburgenses) mostly consists of models of letters. ${ }^{28}$ In some cases, it is possible to identify the origin of the texts copied there, but not always. The letters of one of

20 Zeumer 1886, 79-80.

21 John 1936, 93. The reason for that presumption is the mention of a church dedicated to the Virgin Mary.

22 Leiden, Universiteitsbibliotheek, Voss. Lat. O.86. A description of it is in Rio 2009, 246-247.

23 Rio 2009, 108-109.

24 Rio 2009, 242.

25 Munich, Bayerische Staatsbibliothek, Clm 29585/2; see Bischoff 1974, 258; Bischoff 1980, 247. The fragments of the Staatliche Bibliothek Regensburg discovered and published by Jürgen Sydow in 1957 have now been lost (email from Nicole Geiger to my colleague, Christoph Walther, 19 Nov. 2018).

26 Sydow 1957, 525: 'die Textgestaltung schließt sich hier nahe an die [...] Handschrift Clm. 4650 aus Benediktbeuern an, ohne daß man aber direkt von einer Abhängigkeit sprechen könnte'.

27 Zeumer 1883; Zeumer 1886, 461-468 ('Formularum codicis S. Emmerami fragmenta'); Sydow 1957.

28 Most of the Formulae Salzburgenses are models for writing (parts of) letters, but one can find models for charters as well (see Form. Salzb. 4 and 5). 
Charlemagne's most venerated and prominent advisors, the Anglo-Saxon scholar Alcuin, were obviously of great importance in the creation of that collection. ${ }^{29}$ The scribe who wrote out Clm 4650 (or the author of this collection if we assume that Clm 4650 is not an original compilation) had various letters written by Alcuin at his disposal and copied short extracts of them or abbreviated them. He used the beginning and end of a letter to the monks of Monkwearmouth-Jarrow Abbey ${ }^{30}$ and he recycled the last sentence elsewhere in his collection; $;{ }^{31}$ he used the first phrase of that letter and combined it with the beginning of a letter to Aethelhard, archbishop of Canterbury, for another formula ${ }^{32}$ The author of the Salzburg collection also used other letters from and to Alcuin: a letter to Riculf, archbishop of Mainz, ${ }^{33}$ the beginning of a letter to a priest named Monna, ${ }^{34}$ a letter to an unnamed friend celebrating their affection for each other, together with the end of a letter to the king of Mercia, ${ }^{35}$ a letter to Ricbod, archbishop of Trier, ${ }^{36}$ a letter of recommendation for a pilgrim travelling to Rome, ${ }^{37}$ a letter to Arn of Salzburg addressing questions of faith, ${ }^{38}$ a letter to Angilbert, abbot of Corbie $^{39}$ and a letter to Pope Leo III. $^{40} \mathrm{He}$ also quoted the ending of a letter sent to Alcuin by Charlemagne's sister Gisla and one of his daughters (Rodtruda). ${ }^{41}$ The author

29 Bischoff 1973, 10: 'Geplündert wurden dafür die unter Arn angelegten Handschriften der Alkuin-Briefe; neben ganzen ausgeschriebenen Briefen verteilen sich kürzere Entlehnungen in neuen Formeln fast über die ganze Sammlung'. On Alcuin's Letters see Veyrard-Cosme 2013; short allusion to Clm 4650 in Veyrard-Cosme 2013, 82 (the indication of date [“c. 840"] cannot refer to the manuscript but to the compilation of Alcuin's letters).

30 Letter no. 19 (Dümmler 1895, 53 up to 1.15 and 56 1l. 19-22) used for Form. Salzb. 34 (Zeumer 1886, 447).

31 Letter no. 19 (Dümmler 1895, 56 1l. 25-26) used for Form. Salzb. 42 (Zeumer 1886, 449).

32 Letter no. 19 (Dümmler 1895, 53 1l. 9-11) and letter 17 (Dümmler 1895, 45 1l. 12-16) used for Form. Salzb. 43 (Zeumer 1886, 449).

33 Letter no. 35 (Dümmler 1895, 77) used for Form. Salzb. 35 (Zeumer 1886, 447).

34 Letter no. 38 (Dümmler 1895, 80 1l. 21-23) used for Form. Salzb. 40 (Zeumer 1886, 448).

35 Letter no. 39 (Dümmler 1895, 82 up to 1. 25: permaneat fraternitas) used for Form. Salzb. 33 (Zeumer 1886, 447 up to 1.20: permaneat caritas veraque fraternitas); letter 61 (Dümmler 1895, 105: Divina te in omni bonitate pietas florere faciat, fili carissime) used for Divina te in omni bono florere fatiat pietas, fili et frater karissime (Zeumer 1886, 447 1. 23).

36 Letter no. 49 (Dümmler 1895, 93 1l. 11-17 and 22-24) used for Form. Salzb. 36 (Zeumer 1886, 448).

37 Letter no. 140 (Dümmler 1895, 222) used for Form. Salzb. 1 (Zeumer 1886, 439-440).

38 Letter no. 268 (Dümmler 1895, 426-427) used for some questions and answers on God and creation (Rockinger 1858, 151-152: no. XCIX).

39 Letter no. 151 (Dümmler 1895, 247) used (with some modifications) for Form. Salzb. 52 (Zeumer 1886, 450).

40 Letter no. 180 (Dümmler 1895, 298) used for Form. Salzb. 60 (Zeumer 1886, 452-453).

41 Letter no. 196 (Dümmler 1895, 325) used for Form. Salzb. 6 (Zeumer 1886, 441). 
used not only the Anglo-Saxon master's letters, but also other models (for instance Augustine's). ${ }^{42}$ The end of the codex consists of a small collection of letters that Alcuin wrote to Arn of Salbzurg (785-821). Unlike the formulae, these letters were not anonymised. It has been supposed that Arn himself may have adapted Alcuin's letters and diplomatic material to the needs of the archbishopric chancellery ${ }^{43}$ but a closer look at the text does not support that hypothesis. ${ }^{44}$ It is more likely that the collection called Formulae Salzburgenses was made during the episcopate of Archbishop Liupramm (836-859) and Master Baldo. ${ }^{45}$ For that reason it is rather unlikely that $\mathrm{Clm} 4650$ is the original manuscript of this collection of letters; it is probably a copy of a manuscript that has now been lost or is still unknown. ${ }^{46}$ Nevertheless, Archbishop Arn of Salzburg greatly influenced the content of $\mathrm{Clm} 4650$, which is also an important testimony to the intercultural exchange between the core territory of Carolingian power and the periphery: no-one other than Arn, who was also the abbot of Elnone Abbey (today Saint-Amand-les-Eaux in Northern France), was responsible for the introduction of Frankish legal wording to Bavaria (as attested by the Formulae Salicae Lindenbrogianae). ${ }^{47}$

\section{Layout and textual interpretation}

The historians who edited $\mathrm{Clm} 4650$ in the nineteenth century disagreed about the number of texts it contains: $126^{48}$ or $132{ }^{49}$ The reason for that is the difficulty in determining where some texts begin and where they end, as there is not always a clear distinction between formulae. Based on the structure of the collection and on the fact that texts in different places in the manuscript occur in other manuscripts as well, Clm 4650 is most probably a fusion of smaller collections..$^{50}$ One thing is certain, however: the scribe(s) of $\mathrm{Clm} 4650$ made no distinction between

42 Form. Salzb. 54 (Zeumer 1886, 451).

43 Lhotsky 1963, 158-159.

44 Bischoff 1973, 10-11.

45 For more on him, see Bischoff 1980, 78-82.

46 In Theodor Sickel's opinion, Clm 4650 is a copy of Vienna, ÖNB, 808. See Bullough 2002, 74 on the link between both manuscripts.

47 Sonnlechner 2007, 207-221.

48 Rockinger 1858, 5.

49 Rozière 1859, 11.

50 Rozière 1859, 14; Rio 2009, 101-110. The identification of the diverse texts upon which this codex rests is a difficult task and cannot be covered in detail here. 
what we now see as different parts of that collection; there is no codicological distinction, nor any clear separation between the texts copied before the Formulae Salzburgenses and that collection, which is only transmitted in Clm 4650 and begins with a model for writing a letter of recommendation indicated by the heading 'Tractura' (for tractoria, i.e. 'credentials') - similar to many other headings in the codex (Fig. 1). The scribe was obviously aware of at least one thing: he knew that the text he had copied on the last leaf of that quire, which contained various models for charters, was a new model of a letter, as the text copied before that model for a tractoria ends with the word finit ('the end'). It is not really clear, however, if this means 'the end of that particular text' (i.e. the model for a confirmatio regalis - a charter of confirmation issued by the king $)^{51}$ or 'the end of that section' (i.e. the part with models for charters which their editor, Karl Zeumer, thought was a coherent section ending there ${ }^{52}$ ). As we have already seen, $\mathrm{Clm}$ 4650 is a mixture of texts of diverse origin: these templates were parts of various collections in the eyes of Karl Zeumer and his readers, but not necessarily in the eyes of the medieval scribe. One important piece of evidence for the presumption that medieval scribes in or near Salzburg did not regard these templates as different texts that had been grouped together, but as a continuum is palaeographical. Bernhard Bischoff distinguished three different hands: the first transition from one hand to the other is supposed to occur on fol. $16^{\mathrm{r}}$ and the second change is supposed to occur on fol. 69 $9^{v}$. If Bischoff's palaeographical analysis is correct, ${ }^{53}$ then the changes occur in the middle of two formulae and not at the end of a section: the same scribe (the second one, according to Bischoff) copied models of charters and models of letters without any obvious break. In any case, I do not find Bischoff's conclusion entirely convincing (see Fig. 2).

Unlike modern editions, the formulae are not numbered in the manuscript. Some letters contain elements in red ink, but there is no systematic distinction between the different models as such: the scribe used red to underline important words or make subdivisions in his text. He did it in the same manner for parts of one and the same formula as well as between two different formulae. Let us take Form. Salzb. 3-5, for example (the text is shortened and the letters in red are underlined here):

$51 \mathrm{Clm}$ 4650, fols $61^{\mathrm{v}}-63^{\mathrm{r}}$, edition: Zeumer 1886, 126-127 (Formulae Marculfinae aevi Karolini, no. 31).

52 Zeumer 1881, 42-43.

53 Bischoff 1980, 202. The first change is supposed to occur in the middle of Formulae Salicae Lindenbrogianae, Additamenta, no. 1 (edition: Zeumer 1881, 282); the second change is supposed to occur in the middle of Form. Salzb. 10 (Zeumer 1881, 442). 
[Fol. $64^{\mathrm{V}}$ ] End of Form. Salzb. 2: domino sanctissimi fratres. End of the line left blank. Beginning of Form. Salzb. 3 on a new line: Domino eximio meritoque honorabili pio pastori et sanctae sedis presuli $\underline{N}$. humilis servulus vester ...

[Fol. $65^{\mathrm{r}}$ ] End of Form. Salzb. 3: cosmi polique creator! Very little space is left blank. Beginning of Form. Salzb. 4 on a new line: Ille igitur utitur bene de istis transitoriis et caducis rebus ... sempiterna. Quapropter ego in Dei nomine ...

[Fol. $\left.65^{\mathrm{v}}\right]$ Form. Salzb. 4: Christo propitio in omnibus habeant potestatem. Isti sunt testes per aurem tracti, qui ipsam traditionem viderunt et confirmare debent, quorum hic nomina subter tenentur inserta. Actum in mallo publico sub die mensis ill. End of Form. Salz. 4 at the end of a line. Beginning of Form. Salzb. 5 on a new line: Quia pro aeternae beatitudinis memoria necesse est ...

As this example shows, the beginning of each formula is marked by a red letter, but red has also been used to mark the placeholder for the name of the author who wrote the letter 'Form. Salzb. 3' (N.) and in the charter 'Form. Salzb. 4' to mark the beginning of the dispositive clause (quapropter: 'therefore'...) and the beginning of the list of witnesses and another strategic place in that announcement ('those [isti] are the witnesses, who' - according to a specific Bavarian custom - 'have been dragged by the ears, saw how this donation was made and must confirm it, whose [quorum] names are written below'). But there is no rule, and to be honest, such differentiation sometimes makes little sense because the words beginning with a red letter are not all at the beginning of a sentence or another strategic place. Scribes felt free to emphasise certain words and sentences in a way we hardly understand today. Often, however, it is worth trying to understand why they did so because it can help us to see their perception of the structure of the texts they copied and to edit and read them correctly.

\section{Examples of variations}

Writing a medieval letter is something like improvising variations upon a theme. The comparison between two similar texts shows how it works. Let us take a collection of 21 letters as an example. These were copied by Frobenius Forster, the abbot of St Emmeram in Regensburg, on the basis of a ninth-century manuscript, which has since been lost. The collection is structured alphabetically: the first letter begins with the word almifico, the second letter with beatissimo, the third 
with clarissimae, and so on..$^{54}$ This collection, which probably dates from the beginning of the ninth century (one letter was written before 796, another in 807 and a third document may have been written in $814^{55}$ ), contains some models that are similar to letters in the last part of $\mathrm{Clm} 4650 .{ }^{56}$ Obviously there was either a primitive collection which was the source of inspiration for both scribes (the scribe of Bischoff's 'Alphabetische Sammlung' and the scribe of Zeumer's Formulae Salzburgenses) or the scribe who wrote out the Formulae Salzburgenses had the manuscript of Bischoff's 'Alphabetische Sammlung' at his disposal - and not vice versa since the text of letters 2 and 5 of the 'Alphabetische Sammlung' is more accurate than the texts of Form. Salzb. 62 and 60 respectively; these were anonymised more and therefore cannot have been used as models for the 'Alphabetische Sammlung,. ${ }^{57}$ Such models of letters were not transcribed slavishly, however: the scribes took some liberty in copying the formulae, as a comparison between the first item in the 'Alphabetische Sammlung' and Form. Salzb. 59 makes clear (see below; the words that are identical in both are in italics, while the differences are in normal type). The first sentence is almost exactly the same (only one word has been added in the Salzburg model). The occasion is a similar one: in the first case, the writer reminds his addressee of his promise to send more relics of saints and asks him to do so right away; in Form. Salzb. 59, the speaker also alludes to the promise made by the addressee and asks for some medicine. In both cases, the required goods are to be given to the messenger. Both writings are clearly variations on a similar theme. The topic and rhetoric are the same, though. Apart from the beginning, the wording is different throughout:

\begin{tabular}{ll}
\hline $\begin{array}{l}\text { 'Alphabetische Sammlung', no.1 } \\
\text { (Bischoff 1973, 34) }\end{array}$ & $\begin{array}{l}\text { Form. Salzb. 59 } \\
\text { (Zeumer 1886, 452) }\end{array}$ \\
\hline Beginning: & Beginning: \\
Almifico et glorioso et per omnia colendo viro & Almifico et glorioso et per omnia colendo viro \\
ill. Ego ill. In Christi nomine devotus vester & ill. Ego ill. In Christi nomine devotus vester \\
cum totis visceribus in domino lesu Christo & $\begin{array}{l}\text { cum totis visceribus serviens in domino lesu } \\
\text { perpetuam atque rosifluam deposcimus }\end{array}$ \\
salutem et gloriam. & $\begin{array}{l}\text { Christo perpetuam atque rosifluam } \\
\text { deposcimus salutem et gloriam. }\end{array}$ \\
\hline
\end{tabular}

54 Published by Bischoff 1973, 34-42; see Löfstedt and Lanham 1975 on this edition.

55 Bischoff 1973, 13-14.

56 Bischoff 1973, 13. Bischoff mentions seven letters, but in his edition he refers to eight identical models (Formulae Salzburgenses nos 57 and 60-66) and two quite similar texts (Formulae Salzburgenses nos 58-59).

57 Bischoff 1973, 13, 34 and 35. 


\section{'Alphabetische Sammlung', no. 1 (Bischoff 1973, 34) \\ Form. Salzb. 59 \\ (Zeumer 1886, 452)}

Allusion to the promise made by the addressee:

addressee:

Recordare dignetur pia almitas vestra, quod Recurret ad memoriam gloriae dignitatis vestrae, quod nobis bonitas promisit vestra presenti fabulatione medicum unum praestare, nostros egrotos ac infirmos medicinali arte curare.

Request for relics:

Enimvero humiliter deprecamus magnam ac piam prudentiam vestram, ut per praesentem nostrum gerulum eas nobis mittere dignemini, ut Deus glorificetur in illis et vita nostra proficient cum illis et merces vestra in aeterna gloria adcrescat pro illis.

Ending:

Valeat et vigeat magna caritas vestra multis feliciter in hoc saeculo annis et in futuro in caelestibus sedibus atque angelorum coetibus in gloria perpetua vos lesus Christus collocare dignetur, coronam aeternae vita percipere mereamini.
Request for medicine:

Propterea humiliter deprecamur largam missum nostrum eum dirigatis usque ad nos, hac de causa sollicitandi.

Ending:

Nos autem vestrum condignum servitium impendere, undecumque nobis iubere dignetis, parati sumus, sicut dignum est tali viro Deique servo fidelique amico facere. Valete nunc et semper feliciter et in aeternum cum angelorum laudibus choris. clementiam vestram, ut nobis per presentem

Bernhard Bischoff proposed a connection between the Bavarian collections (the 'Alphabetische Sammlung' he edited and the Formulae Salzburgenses edited by Zeumer) and a small collection of ten model letters (Collectio codicis Havniensis 1943 edited by Zeumer) also probably dating from the 820s (one letter is addressed to Pope Paschalis, who reigned from 817 to 824), which is preserved in the Copenhagen manuscript mentioned above $\mathrm{e}^{58}$ and is also organised alphabetically ${ }^{59}$ Bischoff's hypothesis is based on a comparison between the beginning and end of these letters, ${ }^{60}$ but this is not convincing, as the following list of occurrences based on Bischoff's indications in his edition shows (again, the

58 Det Kongelige Bibliotek, Gl. Kgl. Saml. $19434^{\circ}$.

59 Edition: Zeumer 1886, 522-524.

60 Bischoff 1973, 15. 
shared words are in italics); not only does the wording differ significantly, but there is very little overlap between the addressees:

Collectio codicis Havniensis 1943

(Zeumer 1886, 522-524)
Form. Salzb. (Zeumer 1886, 452-455)

$\approx$ 'Alphabetische Sammlung'

(Bischoff 1973, 34-42)

\begin{tabular}{|c|c|c|c|}
\hline $\begin{array}{l}\text { No. } 1 \\
\text { (beg.) }\end{array}$ & $\begin{array}{l}\text { To an emperor: } \\
\text { Almifico adque excellentissimo } \\
\text { domino meo ill., a Deo coronato } \\
\text { magno et pacifico imperatore, } \\
\text { ego ill. humilissimus servulus } \\
\text { vester. }\end{array}$ & $\begin{array}{l}\text { Form. } \\
\text { Salzb. } 59 \\
= \\
\text { Bischoff, } \\
\text { no. } 1 \\
\text { (beg.) }\end{array}$ & $\begin{array}{l}\text { To an important person: } \\
\text { Almifico et glorioso et per omnia } \\
\text { colendo viro ill. ego ill. in Christi } \\
\text { nomine devotus vester cum totis } \\
\text { visceribus (serviens) in domino lesu } \\
\text { Christo perpetuam atque rosifluam } \\
\text { deposcimus salutem et gloriam. }\end{array}$ \\
\hline $\begin{array}{l}\text { No. } 1 \\
\text { (ending) }\end{array}$ & $\begin{array}{l}\text { Valeat gloriosissimus dominus } \\
\text { meus multis feliciter in seculo } \\
\text { annis, et in futuro in angelorum } \\
\text { choro coronam aeternae gloriae } \\
\text { percipere beatissimam mere- } \\
\text { amur. Amen. }\end{array}$ & $\begin{array}{l}\text { Bischoff, } \\
\text { no. } 1 \\
\text { (ending) }\end{array}$ & $\begin{array}{l}\text { Valeat et vigeat magna caritas ves- } \\
\text { tra multis feliciter in hoc saeculo } \\
\text { annis et in futuro in caelestibus } \\
\text { sedibus atque angelorum coetibus } \\
\text { in gloria perpetua vos lesus Christus } \\
\text { collocare dignetur, coronam aeter- } \\
\text { nae vita percipere mereamini. }\end{array}$ \\
\hline $\begin{array}{l}\text { No. } 2 \\
\text { (beg.) }\end{array}$ & $\begin{array}{l}\text { To a king: } \\
\text { Beatissimo et gloriosimo domino } \\
\text { meo illo, christianissimo viro a } \\
\text { Deo et angelis eius electo adque } \\
\text { in imperio sublimato, ego ill. ser- } \\
\text { vulus vester ubique devotus } \\
\text { adque fidelis in omnibus obe- } \\
\text { diens. }\end{array}$ & $\begin{array}{l}\text { Form. } \\
\text { Salzb. } 62 \\
= \\
\text { Bischoff, } \\
\text { no. } 2 \\
\text { (beg.) }\end{array}$ & $\begin{array}{l}\text { To an archbishop } \\
\text { (ad archiepiscopum): } \\
\text { Beatissimo et nutu divino honora- } \\
\text { biliter atque honorifice in cathedra } \\
\text { episcopali sacerdotii dignitati } \\
\text { functo ill. episcopo ill., quamvis in- } \\
\text { dignus, tamen, annuente divina } \\
\text { gratia, abba vocitatus vester ex totis } \\
\text { recordiis fidelis ac devotus famulus } \\
\text { per hanc seriem litterarum nos- } \\
\text { trarum in Deo patre inmarcescibilem } \\
\text { atque in rosifluo odore optamus } \\
\text { perennem salutem. }\end{array}$ \\
\hline
\end{tabular}


Collectio codicis Havniensis 1943

(Zeumer 1886, 522-524)
Form. Salzb. (Zeumer 1886, 452-455)

$\approx$ 'Alphabetische Sammlung'

(Bischoff 1973, 34-42)

\begin{tabular}{ll}
\hline No. 3 & To a queen or another woman (Ad \\
(beg.) & regina sive qualibet femina): \\
& Carissimae aelectae Dei illa ami- \\
& ca sanctorum et socia angelorum \\
& ac consolatrix pauperum et pere- \\
& grinorum ego ill. fidelissimus \\
& serviens vester secundum intel- \\
& legentiam parvitatis nostrae.
\end{tabular}

No. 3 Valeat domine meae genetrix

(ending) gloriosa nunc et semper et in aeterna feliciter Dei gloria cum sanctis angelis perpetualiter.

\section{No. 5 To a bishop (Ad episcopum): \\ (beg.) Eximio et ortodoxo viro a Deo coronato ill. episcopo ego ill. in domino lesu Christo sempiternam obto salutem.}

No. 7 To a brother or a friend (Ad

(beg.) fratrem vel amicum):

Glorioso et venerabiliter desiderando domino meo, germano carissimo illo, ego ill. In fide et caritate et tota dilectione vestram dulcissimam fraternitatem salutem, vitam, pacem et gloriam obtamus in Domino sempiternam.

No. 8 To a sister (Ad sororem):

(beg.) Karissime itaque desiderantissime sorori meae ill. ego ill. in domino lesu Christo sempiternam salutem.
Form. To a nun (Ad monialem sanctam)
Salzb. 63 Clarissimae virgini, electae Dei et
$=\quad$ amicae sanctorum ac consolatrici
Bischoff, pauperum et peregrinorum ill.
no. 3 sponsa Christi ill. humillimus servus
(beg.) servorum Dei monachus, vester fi- delis in parvitate orationum nos- trarum orator, in rosarum niveoque candore speciem pulchritudinis ves- trae felicem optamus salutem.

Form. Vale, virgo gloriosa, nunc et semper

Salzb. 63 in aeterna feliciter secula.

$=$

Bischoff,

no. 3

(ending)

Form. To the pope (Ad papam):

Salzb. 60 Eximio et orthodoxo, a Deo coronato, $=$ magno viro, gemma a sacerdotum,

Bischoff, ill. summo presuli, sede summa auno. 5 reaque Romana cum gloria et omni

(beg.) honestate feliciter regente, ille vilissimus omnium servorum Dei servus.

Form. To an abbot (Ad abbatem):

Salzb. 65 Glorioso atque spiritu sapientiae re$=\quad$ pleto ill. abbati (...) etenim ill.

Bischoff, vesterque fidelis discipulus in domino. 7 no lesu regi regum felicem deposci(beg.) mus salutem.

Form. (no specific addressee)

Salzb. 58 Karissimo et amabili viro ill. ego ill. $=\quad$ per has apices gloriae dignitatis

Bischoff, vestrae sempiternam ac gloriosam no. 10 opto salutem.

(beg.) 
Collectio codicis Havniensis 1943

(Zeumer 1886, 522-524)
Form. Salzb. (Zeumer 1886, 452-455)

$\approx$ 'Alphabetische Sammlung'

(Bischoff 1973, 34-42)

\begin{tabular}{|c|c|c|c|}
\hline $\begin{array}{l}\text { No. } 9 \\
\text { (beg.) }\end{array}$ & $\begin{array}{l}\text { To a friend (Ad amicum fidelem): } \\
\text { Laudabiliter cum omni dileccione } \\
\text { et amore nominando fideli amico } \\
\text { ill. ego ill. in marcissibilis gloriae } \\
\text { salutem. }\end{array}$ & $\begin{array}{l}\text { Form. } \\
\text { Salzb. } 11 \\
\text { (beg.) }\end{array}$ & $\begin{array}{l}\text { To a friend: } \\
\text { Laudabiliter cum omni dilectione et } \\
\text { amore caritatis amabiliter amplec- } \\
\text { tendo illo fideli amico ille quamvis } \\
\text { exiguus in vincula caritatis Christi } \\
\text { vobis connixus in Deo patre aeterno } \\
\text { aeternamm ac iocundam destina- } \\
\text { mus salute. }\end{array}$ \\
\hline $\begin{array}{l}\text { No. } 10 \\
\text { (beg.) }\end{array}$ & $\begin{array}{l}\text { To a friend (Item ad amicum): } \\
\text { Magnifico viro et honorifice } \\
\text { diligendo illo amico fideli ill. } \\
\text { aeternam salutem. }\end{array}$ & $\begin{array}{l}\text { Bischoff, } \\
\text { no. } 12 \\
\text { (beg.) }\end{array}$ & $\begin{array}{l}\text { Magnopere diligendo et cum summa } \\
\text { veneratione fideliter nominando illo } \\
\text { vilis etenim ille vester devotus } \\
\text { famulus in Christi benedictione } \\
\text { optabilem atque gloriosam optamus } \\
\text { salutem et pacem. }\end{array}$ \\
\hline $\begin{array}{l}\text { No. } 10 \\
\text { (ending) }\end{array}$ & $\begin{array}{l}\text { De aliis quoque causis, unde in- } \\
\text { diguerit, bonitas vestra adiuto- } \\
\text { rium illis inde inpendat. Sic inde } \\
\text { agite, ut in vestram fidi sumus } \\
\text { bonitatem. Bene valeto. }\end{array}$ & $\begin{array}{l}\text { Bischoff, } \\
\text { no. } 12 \\
\text { (ending) }\end{array}$ & $\begin{array}{l}\text { Taliter inde agere studeatis, qualiter } \\
\text { in sanctam ac praeclaram bonitatem } \\
\text { vestram in omnibus semper bonis } \\
\text { freti sumus de vobis. Valete nunc et } \\
\text { semper, vir gloriosissime, feliciter } \\
\text { in Christo lesu et in omnibus sanctis } \\
\text { eius. Amen. }\end{array}$ \\
\hline
\end{tabular}

As Bischoff rightly argued, ${ }^{61}$ the end of the first letter in the Copenhagen collection is similar to the ending of the first piece of the 'Alphabetische Sammlung' he edited:

\section{Collectio codicis Havniensis 1943, no. 1 'Alphabetische Sammlung', no. 1 \\ (Zeumer 1886, 522) (Bischoff 1973, 34)}

Valeat gloriosissimus dominus meus multis feliciter in seculo annis, et in futuro in angelorum choro coronam aeternae gloriae percipere beatissimam mereamur. Amen.
Valeat et vigeat magna caritas vestra multis feliciter in hoc saeculo annis et in futuro in caelestibus sedibus atque angelorum coetibus in gloria perpetua vos lesus Christus collocare dignetur, coronam aeternae vita percipere mereamini.

61 Bischoff 1973, 34. 
But the topic being dealt with is a common one in Christian thought. Therefore this fails to prove that one scribe's inspiration is to be found in one specific text. Many letters end in that manner - although the wording is different, the meaning is still more or less the same. ${ }^{62}$ These formulations are more likely to be variations on a common theme than a faithful copy. Adaption is the core idea of these formulae, as some final examples from the beginning of the 'Formulae Salzburgenses' will show.

On the basis of a letter Alcuin sent to a friend asking him to welcome a pilgrim to Rome, the scribe made a model of a tractoria. For this purpose, he modified the beginning and the end of the original text. The address is transformed and extended into a template for various occasions: the author - called a devoted slave (vernula) of the Church - could be a bishop, an abbot or a count:

\section{Alcuin, letter no. 140 (Dümmler 1895, 222) Form. Salzb. 1 (Zeumer 1886, 439)}

Omnibus venerabilibus viris et diversarum potestatibus dignitatum et sanctae caritatis filiis humilis levita Alchuine sempiternae beatitudinis salutem.

\author{
Omnibus venerabilibus viris et diversarum po- \\ testatibus dignitatum et sanctae caritatis filiis \\ humilis sanctae catholicae et orthodoxae \\ ecclesiae vernula, episcopus scilicet, sive ab- \\ bas aut comis, sempiternae benedictionis in \\ domino Salvatore salutem.
}

62 Collectio Flaviniacensis, no. 117 (h) (Zeumer 1886, 488): Tam multiplices vobis salutis dirigere cupimus et reliqua, obsecrantes piissimo Domino, ut vos una cum culminis sublimitatis vestre longa per tempora trina conservet Deitas, et, quandoque terrena linquetis, suffragantibus sanctis, angelorum mereatis cetibus glomerare, precelentissime et inclite domne. Formulae Sangallenses miscellaneae, no. 7 (Zeumer 1886, 383) and no. 17 (Zeumer 1886, 387): Salus aeterna, quae Christus est, et in hoc presenti tempore vobis longevam salutem et in futuro cum sanctis et electis sempiternam largiri dignetur. Collectio sancti Dionysii, no. 17 (Zeumer 1886, 505): Deus omnipotens evis temporibus in presenti seculo vos sanum et incolomem custodiat et in futuro cum sanctis angelis letabundum efficiat. Amen. Formularum epistolarium collectiones minores: e codice Parisiensi lat. 13090, no. 3 (Zeumer 1886, 530): Non cessat pes tuus, non cessat manus tua, veniet [dies remune]rationis, quando dicetur tibi: 'Venite benedicti et accipe coronam, que tibi a Domino repromissum est'. Rogo insuper, ut memor sis mei, quia ego non obliviscar tui. Vale valeasque perhenniter, amicissime mihi. Formulae extravagantes II, no. 14 (Zeumer 1886, 560): Bene valentem et pro nobis orantem beatitudinis vestrae coronam divina misericordia semper et ubique tueatur atque custodiat. MGH, Epistolae Merowingici et Karolini aevi, vol. 1, 348 (S. Bonifatii et Lulli epistolae, no. 76): Alma trinitas et una divinitas fraternitatem vestram et hic sanctis virtutibus proficientem ac valentem augeat et custodiat et in futura beatitudine, inter splendida angelorum agmina gaudentes remunerando, glorificet. 
The next model, distinguished from the preceding text only by the red colouration of the first letter (Omnibus), is another elaborate template on the same topic. ${ }^{63}$ The address is inspired by imperial diplomas, especially those from Italy (based on the mention of the unique Italian office of the gastaldi): Omnibus venerabilibus viris et fratribus, episcopis, abbatibus, abbatissis, ducibus, comitibus, vicariis, centenariis, castaldiis et omnibus credentibus et Deum timentibus, in partibus Italiae atque Romaniae per monasteria et urbibus atque vicis et villis in Dei nomine permanentibus. This formulation matches the so-called praeceptum negotiatorum, a letter by which Emperor Louis the Pious informed all office-holders in his realm that the merchants named in the document enjoyed his special protection. ${ }^{64}$ Although this text is a unique document that has not been copied wordfor-word in other diplomas, ${ }^{65}$ it is a good example of such a letter of recommendation in a diplomatic context.

After a short letter of congratulation ${ }^{66}$ and two models for making donation charters, ${ }^{67}$ there is a letter assuring the addressee that the author is praying to the Lord for his salvation. The formula contains a model for phrasing the beginning and end of the message (in prose); the author was supposed to write poetry (Cetera metrum) between these two parts. The title 'to a friend of the same age' (Ad amicum coetanum) is not appropriate; the addressee - a bishop - is called 'holy father' (pater sancte) and the author, who has known him 'since his younger days' (a primeva iuventutis flore semper mihi familiares fuistis), is apparently his 'servant' (servulus vester). This is clearly a letter that a former pupil sent to his master. The end is taken from a letter sent to Alcuin by Gisla, Charlemagne's sister:

Alcuin, letter no. 196 (Dümmler 1895, 225)

Form. Salzb. 6 (Zeumer 1886, 441)

Spiritus paraclitus omni veritatis doctrina et

Spiritus paraclitus omni veritatis doctrina et perfectae caritatis scientia vestra impleat perfecte caritatis scientia vestra resplendeat pectora, dulcissime magister. pectora, reverentissime presul. Augeatur vobis salus vitaque perennis!

$63 \mathrm{Clm} 4650$, fols $63^{\mathrm{v}}-64^{\mathrm{r}}=$ Form. Salzb. no. 2 (Zeumer 1886, 440).

64 Zeumer 1886, 314-315 (Formulae imperiales, no. 37); see Ganshof 1957 on that document.

65 Patt 2016, 169.

$66 \mathrm{Clm} 4650$, fols $64^{\mathrm{v}}-65^{\mathrm{r}}=$ Form. Salzb. no. 3 (Zeumer 1886, 440).

$67 \mathrm{Clm} 4650$, fols $65^{\mathrm{r}-\mathrm{v}}=$ Form. Salzb. no. 4 (Zeumer 1886, 440-441): donation to the Church of St Rupert made by a man and his wife, to be effective after their death; Clm 4650, fols $65^{\mathrm{v}}-66^{\mathrm{r}}=$ Form. Salzb. no. 5 (Zeumer 1886, 441): donation to the Monastery of St Peter, to be effective after the donator's death. 
The collection continues - without a visible interruption except for a red initial (Fig. 3) - with a text without a title, ${ }^{68}$ which could be part of the letter before (this interpretation is Dümmler's, who edited the formula as a letter sent to a bishop by a pupil greeting him, but then complaining about his anger). ${ }^{69}$ This text is a collage of religious and moral maxims, which could be taken as a form of homework that a master set his pupil. There are examples of various types of short letters (Incipiunt indicolorum salutes) after that. Again we find an example of a letter that a pupil sent his teacher; ${ }^{70}$ it is an adaption of a letter sent by Alcuin to Charlemagne saying that congratulations proceed from love:

\begin{tabular}{ll}
\hline Alcuin, letter no. 126 (Dümmler 1895, 185) & Form. Salzb. 7 (Zeumer 1886, 442) \\
\hline Solent itaque de fonte caritatis saepius & Solent plerumque de fonte caritatis etiam \\
verba fluere salutationis, vel, si longinquitas & fluere verba salutationis. Nunc vestra melliflua \\
terrarum vocis officia neget, apices & epistola, omni procul dubio auro obrizo dilec- \\
dilectionis atramento formati multoties & tior, ad memoriam reducit, quanta bona \\
recurrant. & quantaque humilitate de vobis, magistro et \\
& pedagogo meo, amatori nostro, quem etiam \\
& nunc intercessorem nostrum, ubicumque est, \\
& nullatenus dubito. \\
\hline
\end{tabular}

The next example (item alia) is a letter to a spiritual leader - possibly a bishop sent by the head of a religious community. ${ }^{71}$ This model was copied quite accurately later in that same collection:

Form. Salzb. 8 (Zeumer 1886, 442)

Form. Salzb. 26 (Zeumer 1886, 446)

Domino sancto et venerabili patri ill. ill. una cum

Domino sancto ac venerabili atque desiderabili ceteris famulis ac fidelibus vestris die noctuque oratoribus in sancta religione degentibus in dilectione Dei patris et asparsione sanguinis lesu Christi sanctique Spiritus amore salutem. Notum ergo sit vobis, venerabilis pater, quod ... patri ill. ill. una cum ceteris famulis ac fidelibus die noctuque oratoribus in ill. congregatione degentibus in dilectione Dei patris et asparsione sanguinis lesu Christi sanctique Spiritus amore salutem.

68 Rockinger 1858, 133-134 (the text begins with the words Iam quondam fidelis mentem inpatiens furor ...). Zeumer did not edit this text.

69 Dümmler 1895, 498-500 (Epistolae variorum, no. 5): Episcopum quendam discipulus eius salutat eique de iracundia cuiusdam queritur.

$70 \mathrm{Clm}$ 4650, fol. 68 ${ }^{\mathrm{v}}=$ Form. Salzb. no. 7 (Zeumer 1886, 441-442).

$71 \mathrm{Clm} 4650$, fol. $68^{\mathrm{v}}=$ Form. Salzb. no. 8 (Zeumer 1886, 442). 
We could pursue this brief analysis of the Salzburg collection further and make other comparisons, but it would turn out to be quite repetitive: the originality of the texts assembled here is not to be found in the idiosyncrasy of the thoughts presented in these formulae, but in the way in which the scribe put familiar models together to create a new patchwork or collage. The originality of these formulae rests upon the adaption of old models in new compilations.

\section{References}

Bierbrauer, Katharina (1990), Die vorkarolingischen und karolingischen Handschriften der Bayerischen Staatsbibliothek. Text- $u$. Tafelband, Wiesbaden: Reichert.

Bischoff, Bernhard (1973), Salzburger Formelbücher und Briefe aus Tassilonischer und Karolingischer Zeit, Munich: Bayerische Akademie der Wissenschaften.

Bischoff, Bernhard (1974), Die südostdeutschen Schreibschulen und Bibliotheken in der Karolingerzeit, I: Die bayrischen Diözesen, Wiesbaden: Harrassowitz.

Bischoff, Bernhard (1980), Die südostdeutschen Schreibschulen und Bibliotheken in der Karolingerzeit, II: Die vorwiegend österreichischen Diözesen, Wiesbaden: Harrassowitz.

Brown, Warren Curtis (2009), 'Die karolingischen Formelsammlungen - warum existieren sie?', in Peter Erhart, Karl J. Heidecker and Bernhard Zeller (eds), Die Privaturkunden der Karolingerzeit, Dietikon (Zürich): Urs Graf, 95-102.

Brown, Warren Curtis (2013), 'Laypeople and documents in the Frankish formula collections', in Warren Brown, Marios Costambeys, Matthew Innes and Adam Kosto (eds), Documentary Culture and the Laity in the Early Middle Ages, Cambridge: Cambridge University Press, 125-151.

Bullough, Donald Auberon (2002), Alcuin: Achievement and Reputation, Leiden: Brill. Constable, Giles (1976), Letters and Letter-collections, Turnhout: Brepols.

Depreux, Philippe (forthcoming), 'Letter or charter? A modern typology against medieval practices: the example of early medieval formulae', in Laura Carlson and Diana Jeske (eds), Brill's Companion to Medieval Letters and Letter Writing, Leiden: Brill.

Ganshof, François Louis (1957), 'Note sur le praeceptum negotiatorum de Louis le Pieux', in Studi in onore di Armando Sapori, I, Milan: Istituto editoriale Cisalpino, 101-112.

Glauche, Günter (1994), Katalog der lateinischen Handschriften der Bayerischen Staatsbibliothek München. Die Pergamenthandschriften aus Benediktbeuern: Clm 4501-4663, Wiesbaden: Harrassowitz.

John, Wilhelm (1936), 'Formale Beziehungen der privaten Schenkungsurkunden Italiens und des Frankenreiches und die Wirksamkeit der Formulare', Archiv für Urkundenforschung, 14: 1-104.

Lhotsky, Alphons (1963), Quellenkunde zur mittelalterlichen Geschichte Österreichs, Graz: Böhlau.

Löfstedt, Bengt and Carol D. Lanham (1975), 'Zu den neugefundenen Salzburger Formelbüchern und Briefen', Eranos, 73: 69-100. 
Patt, Sarah (2016), Studien zu den 'Formulae imperiales': Urkundenkonzeption und Formulargebrauch in der Kanzlei Kaiser Ludwigs des Frommen (814-840), Wiesbaden: Harrassowitz.

Perelman, Les (1991), 'The medieval art of letter writing: rhetoric as institutional expression', in Charles Bazerman and James Paradis (eds), Textual Dynamics of the Professions: Historical and Contemporary Studies of Writing in Academic and Other Professional Communities, Madison, WI: University of Wisconsin Press, 97-119.

Rio, Alice (2009), Legal Practice and the Written Word in the Early Middle Ages: Frankish Formulae, c. 500-1000, Cambridge: Cambridge University Press.

Rockinger, Ludwig (1858), Drei Formelsammlungen aus der Zeit der Karolinger, Munich: Franz.

Rozière, Eugène de (1859), 'Formules inédites publiées d'après deux manuscrits des bibliothèques royales de Munich et de Copenhague', Revue historique de droit français et étranger, 5: 1-65.

Schröder, Richard (1892), 'Arno, Erzbischof von Salzburg und das Urkundenwesen seiner Zeit', Neue Heidelberger Jahrbücher, 2: 165-171.

Sickel, Theodor (1875), Alcuinstudien, Vienna: Karl Gerold's Sohn [offprint from: Sitzungsberichte. Akademie der Wissenschaften in Wien, Philosophisch-Historische Klasse, 79/9: 461-550].

Sonnlechner, Christoph (2007), 'Die Etablierung Salzburgs als Netzknoten: Karolingische Kirchenstruktur, Raumstrategien und Organisation der Landnutzung um 800', in Caspar Ehlers (ed.), Deutsche Königspfalzen. Beiträge zu ihrer historischen und archäologischen Erforschung, Vol. 8: Places of power, Orte der Herrschaft, Lieux du pouvoir, Göttingen: Vandenhoeck \& Ruprecht, 199-226.

Sydow, Jürgen (1957), 'Neue Fragmente der Formulae S. Emmerami’, Deutsches Archiv für Erforschung des Mittelalters, 13: 525-529.

Veyrard-Cosme, Christiane (2013), Tacitus nuntius. Recherches sur l'écriture des Lettres d'Alcuin (730 ?-804), Paris: Institut d'Études Augustiniennes / Brepols: Turnhout.

Ysebaert, Walter (2015), 'Medieval letters and letter collections as historical sources: methodological questions, reflections, and research perspectives (sixth-fifteenth centuries)', in Christian Høgel and Elisabetta Bartoli (eds), Medieval Letters: between Fiction and Document, Turnhout: Brepols, 33-62.

Zeumer, Karl (1881), 'Über die älteren fränkischen Formelsammlungen', Neues Archiv der Gesellschaft für ältere deutsche Geschichtskunde, 6: 9-115.

Zeumer, Karl (1883), 'Über Fragmente einer Formelhandschrift des IX. Jahrhunderts', Neues Archiv der Gesellschaft für ältere deutsche Geschichtskunde, 8: 601-605.

Zeumer, Karl (ed.) (1886), Formulae Merowingici et Karolini aevi (= Monumenta Germaniae Historica, Fontes iuris, Formulae, 1), Hanover: Hahn. 


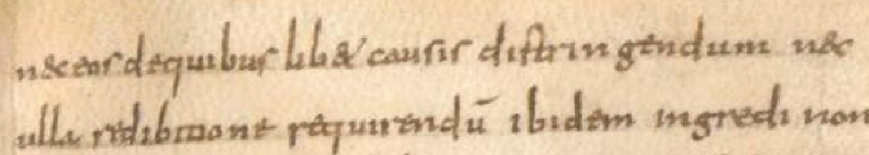

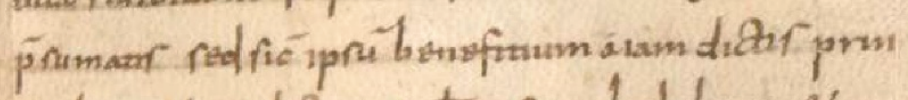
apubur. adianditam acetam fur Indultrm \& Domur Inconualrampmanfoz ha Rdincepe

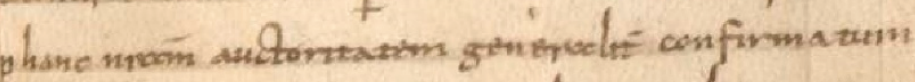
Indinamine peunte maniat inconuulfism \&

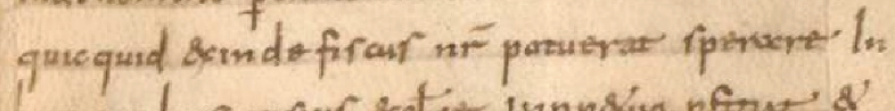

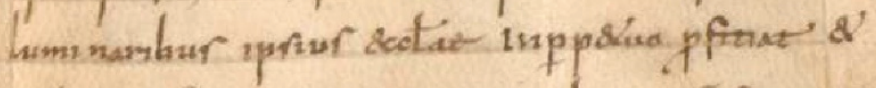

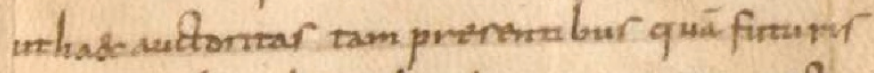

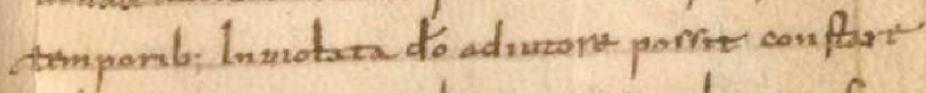

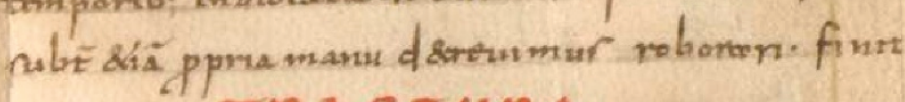

\section{IRACTCRA}

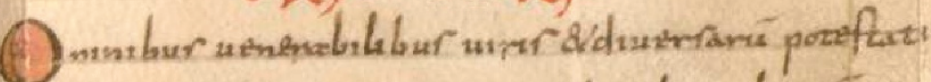



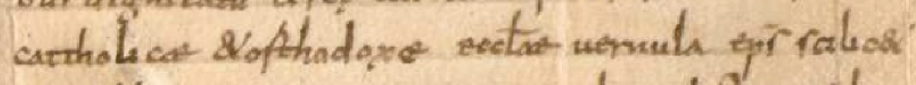

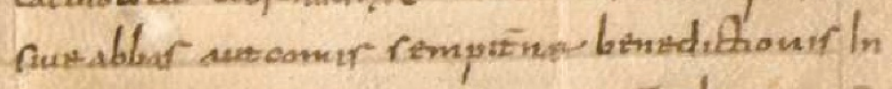

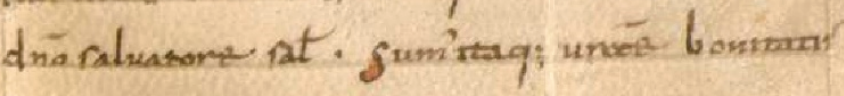

Fig. 1: Clm 4650, fol. 63' (beginning of the 'Salzburg formulae collection'); courtesy of the Bayerische Staatsbibliothek, Munich. 


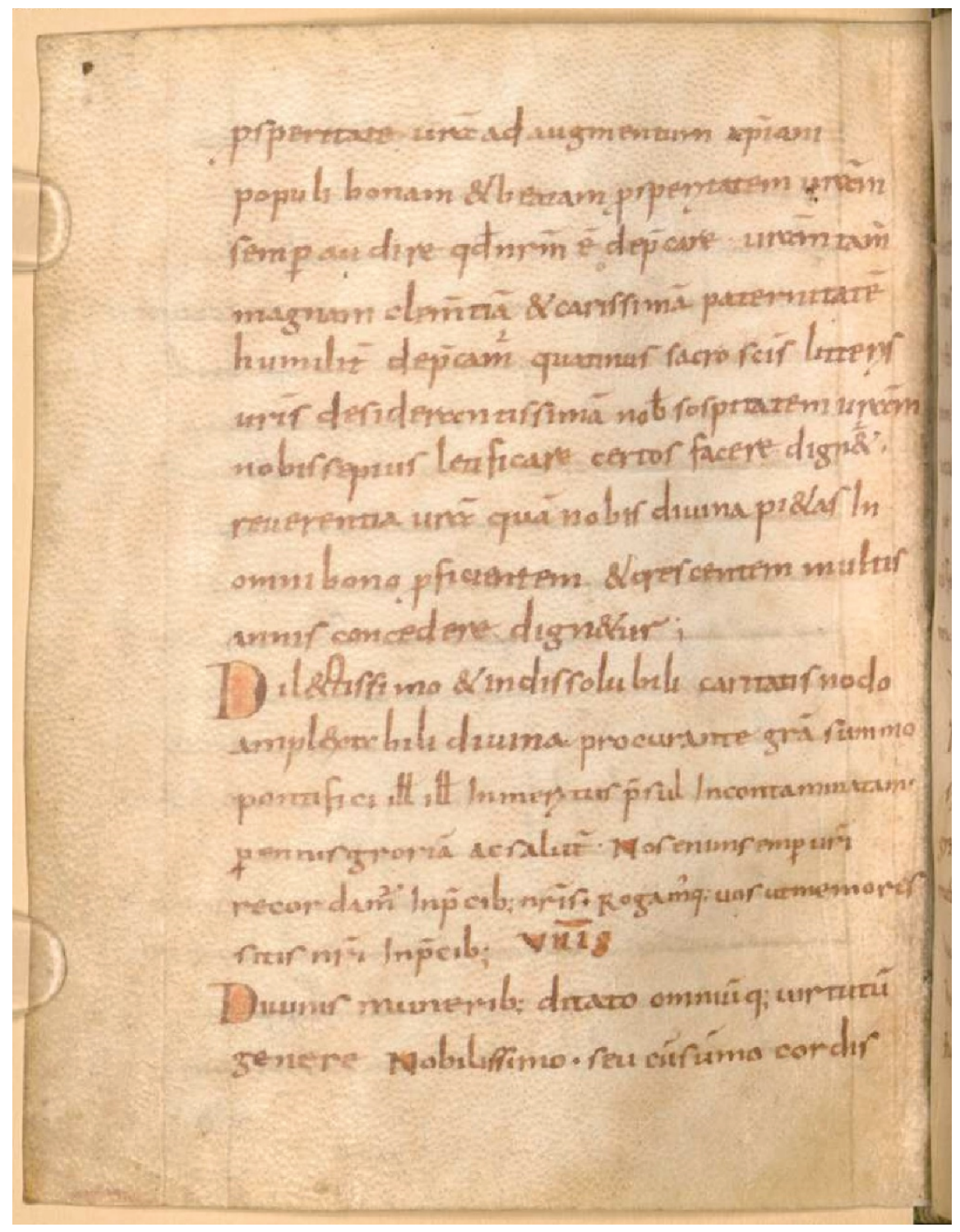

Fig. 2: Clm 4650, fol. $69^{v}$ (with a supposed change of writing hand at line 12); courtesy of the Bayerische Staatsbibliothek, Munich. 


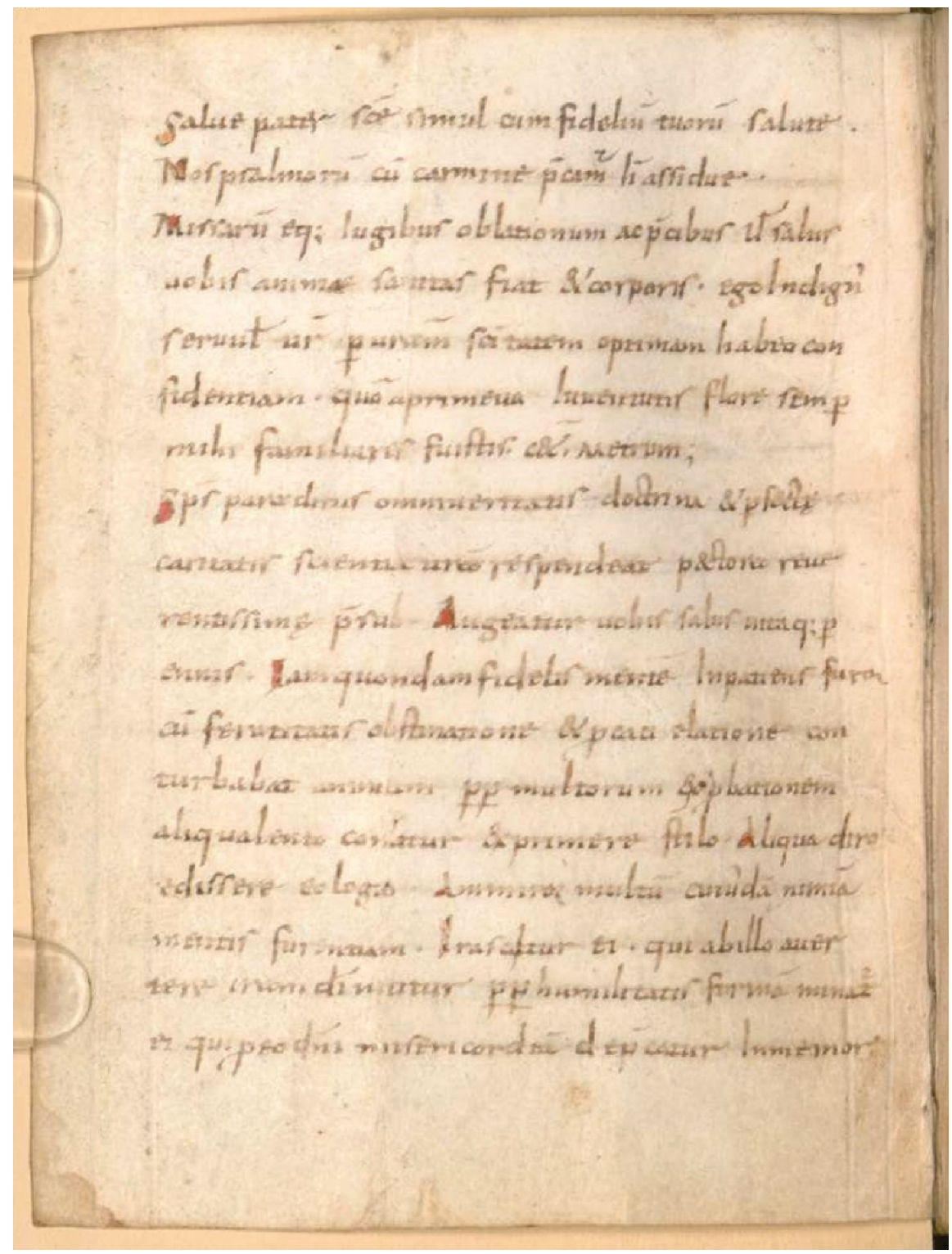

Fig. 3: Clm 4650, fol. $66^{v}$; courtesy of the Bayerische Staatsbibliothek, Munich. 
